\title{
Changes of forest fire regime and landscape pattern under different harvesting modes in a boreal forest of Northeast China
}

\author{
CHEN Hongwei ${ }^{1,2^{*}}$, HU Yuanman², CHANG Yu², BU Rencang ${ }^{2}$, LI Yuehui², LIU Miao² \\ ${ }^{1}$ Liaoning Key Laboratory of Urban Integrated Pest Management and Ecological Security, Shenyang University, Shenyang \\ 110044, China; \\ ${ }^{2}$ State Key Laboratory of Forest and Soil Ecology, Institute of Applied Ecology, Chinese Academy of Sciences, Shenyang \\ 110164, China
}

\begin{abstract}
Forest management such as timber harvesting shapes fire regimes and landscape patterns, and these patterns often differ significantly from those under natural disturbances. Our objective was to examine the effects of timber harvesting modes on fire regimes and landscape patterns in a boreal forest of Northeast China. We used a spatially explicit landscape model, LANDIS, to simulate the changes of forest landscape in the Huzhong forest region of the Great Khingan Mountains under no-cutting, clear-cutting, gradual-cutting and selective-cutting modes. Results showed that: (1) the fine fuel loadings generally decreased while the coarse fuel loadings increased with the increase of timber harvesting intensity; (2) the potential burn area significantly varied among different cutting modes, but the potential fire frequency had no obvious difference. Moreover, timber harvesting generally increased the potential fire risk; (3) clear-cutting mode significantly decreased the mean patch size and the aggregation of larch forests and increased the mean patch size and the aggregation of white birch forests. Therefore, clear-cutting mode should be abandoned, and selective-cutting mode be recommended for the sustainable forest management in the Great Khingan Mountains.
\end{abstract}

Keywords: LANDIS; clear-cutting; gradual-cutting; selective-cutting; Great Khingan Mountains

Citation: CHEN Hongwei, HU Yuanman, CHANG Yu, BU Rencang, LI Yuehui, LIU Miao. 2015. Changes of forest fire regime and landscape pattern under different harvesting modes in a boreal forest of Northeast China. Journal of Arid Land, 7(6): 841-851. doi: 10.1007/s40333-015-0015-2

The forests in the Great Khingan Mountains of Northeast China provide more wood production than those in other forested regions of the country (Zhou, 1991). The Great Khingan Mountains also encompasses unique ecological and environmental characteristics (Xu, 1998). For example, fire is the most important natural disturbance in this region, which regulates species composition and age structure across a forest landscape (Bond and Keeley, 2005; Flannigan et al., 2009). Fire regimes were significantly altered by human activities during the $20^{\text {th }}$ century worldwide. For example, the long-term fire suppression, coupled with a warmer and drier climate, had led to fuel buildup and resulted in fires burn with greater intensi- ty and extent than those occurred historically (Keane et al., 2013). Fire suppression, timber harvesting and other human activities have significantly altered the forest composition, structure, ecosystem process and landscape pattern (Pausas, 2006; Shang et al., 2007; MacDonald et al., 2014). Natural coniferous forests and mixed broadleaf Korean pine (Pinus koraiensis) forests in the Great Khingan Mountains have changed into secondary deciduous forests with non-commercial species such as white birch (Betula platyphylla) and wild poplar (Populus davidiana) (Bu et al., 2008). Moreover, timber harvesting has fragmented the forest landscape with many young forest patches (Bataineh et al., 2013).

\footnotetext{
"Corresponding author: CHEN Hongwei (E-mail: chenhw@iae.ac.cn)

Received 2014-10-24; revised 2015-05-17; accepted 2015-07-10

(C) Xinjiang Institute of Ecology and Geography, Chinese Academy of Sciences, Science Press and Springer-Verlag Berlin Heidelberg 2015
} 
In 1998, the Chinese government designed a sustainable forest development plan, namely the Natural Forest Protection Project (NFPP). According to the NFPP, forests are divided into two categories: commercial forests and non-commercial forests. Commercial forests are the source of timber harvesting (Zhang and Tang, 2007), and non-commercial forests are protected from any human intervention including harvest and other activities.

Some forest landscape ecologists suggested employing the natural disturbance as a guideline for forest management. That is, trying to mimic effects of disturbances on landscape processes and patterns by spatially allocating silvicultural treatments and harvests across a forest landscape (Hunter, 1993; Radeloff et al., 2006). For example, some previous studies suggested that clear-cutting should be allocated at locations where crown fires are common (Rudnicky and Hunter 1993). In contrast, selective-cutting of boreal forests should be more appropriate in areas where single-tree gap dynamics are prevalent (Lorimer, 1977; Wallin et al., 1996). However, which method is appropriate for managing forest fire in the Great Khingan Mountains in northern China is unclear.

It has been demonstrated that landscape pattern strongly affects ecosystem processes (Turner, 1989; Turner et al., 2001). For example, species with poor disperser ability cannot establish themselves in the center of large fire patches (Franklin and Forman, 1987; He and Mladenoff, 1999). Therefore, it is important to examine how forest managements change disturbance processes and then landscape pattern (Foster et al., 1998). For example, fire suppression alters fire regimes, which indirectly change forest landscape patterns (Shang et al., 2007). And forest timber harvesting also affects landscape pattern directly (Gustafson et al., 2000; Rüger et al., 2007). However, how harvest modes influence the forest fire regime (fire frequency, potential burn area, etc.) and forest landscape (species composition, aggregation index, etc.) in Northeast China are not well understood.

Field experiments are often inadequate for managers to develop and implement forest management plans at large scales (Gardner et al., 1999; Mladenoff,
2004). Because comparing forest management strategies effectiveness on a large landscape is beyond the ability of experimental studies that often conducted at a fine scale. Computer simulation models have therefore become effective tools for exploring the effects of alternative management strategies at large scales (Gustafson et al., 2000). Spatially explicit forest landscape models are particularly useful for such studies. By contrast, gap models and ecosystem process models are often limited in a spatial or temporal extent (Mladenoff and He, 1999). Therefore, we used a spatially explicit forest landscape model, LANDIS, to evaluate effects of timber harvesting modes on the long-term fire regimes and landscape patterns in the forests of the Great Khingan Mountains. Specifically, we asked the following three questions: (1) how harvest modes differed in controlling forest fuel loadings? (2) how fire regimes response to the harvest modes? and (3) how forest composition and spatial pattern vary with harvesting modes? Our study could be used to provide insights into improving forest management in the Great Khingan Mountains.

\section{Materials and methods}

\subsection{Study area}

The study area, Huzhong Forest Bureau, is located at the Great Khingan Mountains of Northeast China $\left(51^{\circ} 14^{\prime}-52^{\circ} 25^{\prime} \mathrm{N}, 122^{\circ} 39^{\prime}-124^{\circ} 21^{\prime} \mathrm{E}\right.$; Fig. 1) and covers an area of $937,244 \mathrm{hm}^{2}$. This region belongs to the cool temperate zone with a long and severe winter. The annual average temperature is $4.7^{\circ} \mathrm{C}$ and annual precipitation is $500 \mathrm{~mm}$ (Hu et al., 2004). The vegetation of this region belongs to the transition zone from the eastern Siberian boreal forests to the southern temperate broadleaf forests. The landscape is dominated by the Dahurian larch (Larix gmelini), a late-top species that occupies moist and cooler sites. White birch (Betula platyphylla) is the mostly widely distributed broadleaf tree species. Two early-successional aspen species (Populus davidiana, P. suaveolens) are mixed with larch in most areas due to fire and timber harvesting. Other species, such as Mongol Scotch pine (Pinus sylvestris var. mongolica), Koyama spruce (Picea koraiensis), willow (Chosenia arbutifolia) and Pinus pumila (occurs mostly at elevation $>800 \mathrm{~m}$ ) are 
interspersed with larch forest, and area of $P$. pumila cohorts is very small $(<1.8 \%)$.

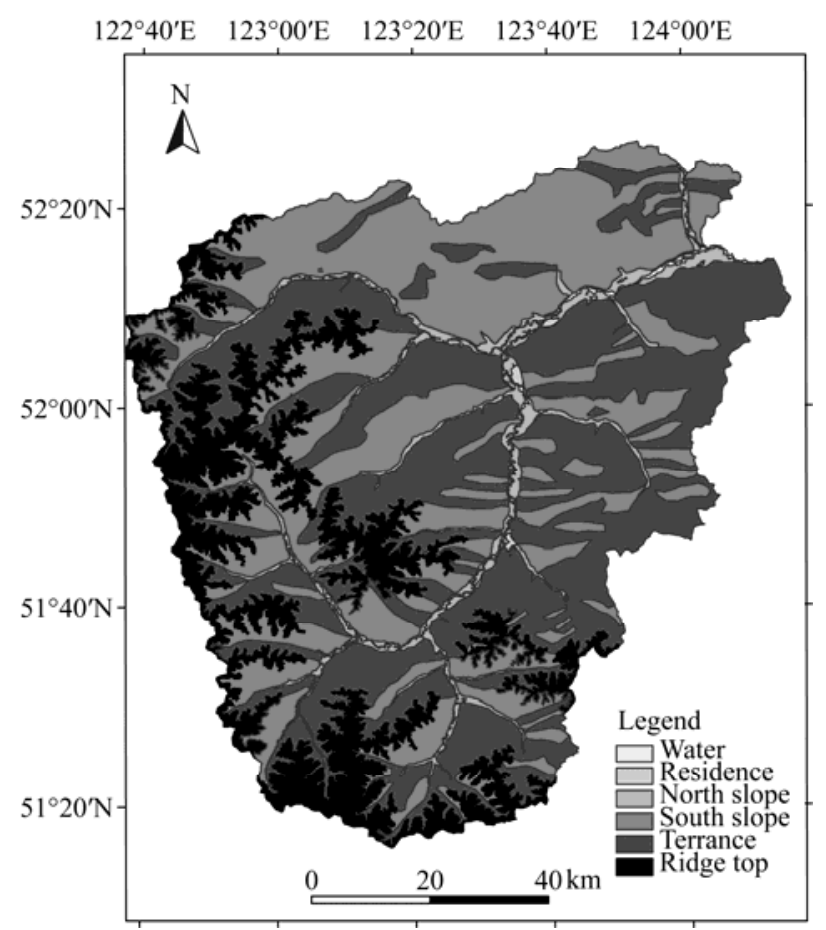

Fig. 1 Location and land type of the study area

The Huzhong Forest Bureau was established in 1960s, and timber harvesting began in 1970s. The timber harvesting modes include clear-cutting, gradual-cutting and selective-cutting. The average fire area was $223 \mathrm{hm}^{2}$ between 1980 and 2010 (Chang et al., 2008). The timber harvesting and fire have strongly altered ecosystem structure and succession dynamics in our study area. Commonly, even-aged stands of pioneer species (e.g. birch and aspen) occupy the open spaces quickly post stand-replacing fires or high intensive timber harvestings (Zhou, 1991). The shade-tolerant species (e.g. larch and pine) then colonize and co-exist with the broadleaf species for the next 80-100 years. The short-lived broadleaf species (longevity of about 150 a broadleaf tree, e.g. white birch, willow and aspen) gradually die and give the way to a climax community of long-lived conifers (about 300 a, e.g. larch and spruce).

\subsection{LANDIS model}

LANDIS 4.0 is a spatially explicit forest landscape succession and disturbance model that facilitates the study of the effects of natural and human disturbances, vegetation succession and management strategies on forest landscapes. LANDIS has been successfully used in many regions and ecosystems (Franklin et al., 2001; He et al., 2004; Sturtevant et al., 2004; Shang et al., 2007; Wang et al., 2007). It is a raster-based model that simulates species establishment, growth, senescence, regeneration, random mortality and vegetative reproduction based on species establishment coefficients and species vital attributes at a cell scale (Mladenoff and He, 1999). LANDIS stratifies a heterogeneous landscape into different land types, which typically are generated from GIS layers of climate, soil or terrain attributes (e.g. slope, aspect and landscape position). It is assumed that a single land type contains a uniform suite of ecological characteristics, resulting in similar species establishment patterns, fire disturbance intensity and fuel decomposition rates (He et al., 2002a). In LANDIS, vegetation succession dynamics are simulated at a site level and the succession process is driven by species life history traits such as shade tolerance, seeding ability, longevity and vegetative reproductive capability (He et al., 2002a). We used a set of logical rules based on the combination of these traits and environmental suitability of each cell to simulate species birth, growth, competition and death (Mladenoff et al., 1996).

The harvest mode of LANDIS is designed in a hierarchical structure. The LANDIS harvest module simulates harvesting activities within management areas (MAs), which are spatial zones (not necessarily contiguous) specified management objectives (Gustafson et al., 2000). The whole landscape is then divided into various MAs, each to be treated with specific harvest modes. Within each MA, timber harvesting is conducted by removing specific cohorts of specific species on sites selected for harvesting (Gustafson et al., 2000). The order in which stands to be harvested is determined by the stand age (Gong et al., 2006). Parameterization of LANDIS for our study area involved: estimating species' vital attributes, generating a forest composition map containing individual species presence/absence and age classes for each pixel, defining fire disturbance regimes parameters for each land type and developing parameters to define the forest harvest modes (Liu et al., 2013). 
The LANDIS fire module simulates fire occurrence, fire spread and the killing of species cohorts on each burned pixel. It simulates fire severities based on the interactions of fire intensity (five intensity levels from surface to crown fires), species fire tolerance (five tolerance levels from the most intolerant to the most tolerant) and age cohort susceptibility (five susceptibility levels from the most susceptible to the least susceptible, based on age) (He et al., 2004). In LANDIS modeling, pixels have higher fuel loadings would burn more intensely fires. In this study, we determined the species fire tolerance level and age susceptibility based on the physiological characteristics of species, which were derived from the literatures and expert knowledge (Chang et al., 2008; Wu et al., 2011). The interaction-effects of fire intensity, species fire tolerance and age susceptibility were simulated in the fire module. The LANDIS fire module produced maps of fire intensity, species composition and age structure, which were used to derive fire severity and its spatial variability. The interactions of fire with species fire tolerance and age susceptibility had been explicitly defined in the research of He and Mladenoff (1999).

Surface fuels are generally classified into two types: fine fuels and coarse fuels. Fine fuels are primarily litters and small dead twigs falling from live trees. Fine fuels are less than $1 / 4$ inch in diameter typically. The 1- and 10-h time-lag fuels are primary determinants of fire ignitions. Coarse fuels, also called coarse woody debris (CWD), include any dead tree materials that have a diameter $\geq 3$-inch (He et al., 2004). Coarse fuel loadings affect the fire intensity. The potential burn area is calculated by the burned area at each decade (He et al., 2004). Potential fire risk is determined by the potential fire intensity and fire probability. Fire probability is a numerical quantity derived from fire cycle and the time since last fire for each cell in LANDIS (He and Mladenoff, 1999). In the LANDIS fuel module, we converted the fire probability into five classes (from very low to very high) based upon the "equal area" (the fire probability density function is divided into 5 areas of equal size) or equal interval approach, and how the fuel influence the forest fire can be concluded from LANDIS user guide (Mladenoff et al., 1996).

\subsection{Parameterization of LANDIS}

1.3.1 Characteristics of species and forest composition The forest composition map was generated from a 1990s forest inventory map, which contains species composition, site conditions and disturbance history. Eight common tree species were included in our LANDIS simulations (Table 1). Life history of forest species was derived from previous LANDIS parameterization of the region (Liu et al., 2012) and suggestion of local forest managers. It is assumed that all tree species are randomly distributed in a stand with different proportions according to the forest inventory data (Mladenoff and He, 1999). A species composition map, including species and age information, was derived from a forest inventory map and database developed in 2000s. This database provided information about stand boundaries and the relative abundance of canopy species, average age of dominant canopy species and timber production of each stand.

\subsubsection{Land type map}

We derived six land types based on terrain attributes

Table 1 Characteristics of species in the study area

\begin{tabular}{|c|c|c|c|c|c|c|c|c|}
\hline Plant species & $\begin{array}{l}\text { Longevity } \\
\text { (a) }\end{array}$ & $\begin{array}{c}\text { MTR } \\
\text { (a) }\end{array}$ & ST & FT & $\begin{array}{l}\text { ED } \\
(m)\end{array}$ & $\begin{array}{l}\text { MD } \\
(\mathrm{m})\end{array}$ & VP & $\begin{array}{c}\text { MVP } \\
\text { (a) }\end{array}$ \\
\hline Larch (Larix gmelini) & 300 & 20 & 3 & 4 & 100 & 200 & 0.0 & 0 \\
\hline Mongol Scotch pine (Pinus sylvestris var. mongolica) & 210 & 40 & 1 & 2 & 50 & 200 & 0.0 & 0 \\
\hline Spruce (Picea koraiensis) & 300 & 30 & 5 & 2 & 50 & 150 & 0.0 & 0 \\
\hline White birch (Betula platyphylla) & 150 & 15 & 1 & 3 & 200 & 2,000 & 0.8 & 40 \\
\hline Aspen-d (Populus davidiana) & 180 & 30 & 1 & 3 & -1 & -1 & 1.0 & 40 \\
\hline Aspen-s (Populus suaveolens) & 150 & 25 & 1 & 5 & -1 & -1 & 1.0 & 40 \\
\hline Willow (Chosenia arbutifolia) & 250 & 30 & 2 & 2 & -1 & -1 & 0.9 & 30 \\
\hline Siberian dwarf pine (Pinus pumila) & 250 & 30 & 3 & 1 & 50 & 100 & 0.0 & 0 \\
\hline
\end{tabular}

Notes: MTR, age of maturity; ST, shade tolerance class (1 to 5, with 1 for the most shade intolerant and 5 for the most shade tolerant); FT, fire tolerance class ( 1 to 5 , with 1 for the least tolerant and 5 for the most tolerant); ED, effective seeding distance; MD, maximum seeding distance; VP, vegetative reproduction probability; MVP, minimum age of vegetative reproduction. 
interpreted from a 1990 Landsat TM imagery and a digital elevation model (DEM). Non-active land types, including water and residential land, accounted for $0.76 \%$ of the total area. Active land types, including south slope, north slope, terrace and ridge top, accounted for $4.78 \%, 37.25 \%, 42.53 \%$ and $14.68 \%$ of the total area, respectively (Fig. 1). For reducing the simulation time of LANDIS, we resampled land type map with a resolution of $90 \mathrm{~m} \times 90 \mathrm{~m}$. Based on the environments, each land type had the same species establishment coefficient derived from previous LANDIS parameterization of this region (Table 2).

\subsubsection{Harvest model}

The forest classified-management-strategy was initialized in 2000 in the area. The spatial distributions of classified forest management area (MA) were derived from a forest stand map. The harvesting intensity was set as $5 \%$ of the total forest area every decade. Harvesting modes included clear-cutting, selective-cutting and gradual-cutting. The clear-cutting removed all the trees, selective-cutting removed the over-mature forest firstly, and then gradually removed the mature and over-mature forest. Gradual-cutting removed the over-mature forest, and cut $10 \%$ of mature and over-mature cohorts every two decades (Table 3).

\subsubsection{Fire module}

We parameterized the fire regime (e.g. mean return interval, ignite coefficient and time since last fire) based on fire records from 1980 to 2000 . The fire return interval was estimated by calculating the reciprocal of the annual proportion of burned forest area within each land type (Yang et al., 2004). Only those fires greater than the resolution of the simulation $(0.81$ $\mathrm{hm}^{2}$ ) were employed to parameterize the fire regimes (Table 4). The parameters of ignition coefficient and time since last fire were derived from previous research results in our study area (Chang et al., 2008).

Table 2 Characteristics for each land type of study area

\begin{tabular}{ccccccccc}
\hline \multirow{2}{*}{ Land type } & \multicolumn{5}{c}{ Species establishment coefficients } \\
\cline { 2 - 7 } & Larch & Mongol Scotch pine & Spruce & White birch & Aspen-d & Aspen-s & Willow & Siberian dwarf pine \\
\hline South slope & 0.40 & 0.20 & 0.03 & 0.30 & 0.20 & 0.00 & 0.00 & 0.00 \\
North slope & 0.40 & 0.10 & 0.05 & 0.20 & 0.20 & 0.00 & 0.00 & 0.00 \\
Ridge top & 0.30 & 0.08 & 0.00 & 0.05 & 0.00 & 0.00 & 0.00 & 0.07 \\
Terrace & 0.01 & 0.00 & 0.00 & 0.05 & 0.05 & 0.20 & 0.00 \\
\hline
\end{tabular}

Table 3 Harvesting parameters of Huzhong forest region

\begin{tabular}{lccc}
\hline & Clear cutting & Selective cutting & Gradual cutting \\
\hline $\begin{array}{l}\text { Percent of harvest area (\%) } \\
\text { Harvest selection criterion of species }\end{array}$ & 5 & 5 & 5 \\
$\begin{array}{l}\text { Harvest selective criterion of forest age } \\
\text { structure }\end{array}$ & $\begin{array}{l}\text { All age structure } \\
\text { cohorts }\end{array}$ & $\begin{array}{l}\text { Mature and over-mature } \\
\text { cohorts }\end{array}$ & $\begin{array}{l}10 \% \text { of mature and over-mature cohorts } \\
\text { every 20 years }\end{array}$ \\
\hline
\end{tabular}

Table 4 Forest fire parameters of Huzhong forest region

\begin{tabular}{lccc}
\hline Land type & $\begin{array}{c}\text { Fire inter- } \\
\text { val (a) }\end{array}$ & $\begin{array}{c}\text { Ignition } \\
\text { coefficient }\end{array}$ & $\begin{array}{c}\text { Time since last } \\
\text { fire (a) }\end{array}$ \\
\hline South slope & 600 & 0.5 & 300 \\
North slope & 500 & 0.4 & 250 \\
Ridge top & 400 & 0.6 & 200 \\
Terrace & 1,500 & 0.3 & 750 \\
\hline
\end{tabular}

\subsubsection{Management area}

According to the NFPP, the forests in our study region were classified into two types: non-commercial forests and commercial forests. The management area was derived from attributes of the forest map, and commercial forests cover $41 \%$ of the study area (Fig. 2). In our study area, the harvesting area accounts about 5\% of the whole forest. Thus, we set the area cut at 5\% per decade for clear- and selective-cutting, and area cut at $10 \%$ every two decades for gradual-cutting.

\subsubsection{Data analysis}

We compared the mean fuel loading, potential fire risk, potential fire intensity and potential fire frequency among the timber harvesting modes. We take the larch 
and white birch as the representative species in our study area, to represent the change of forest landscape.

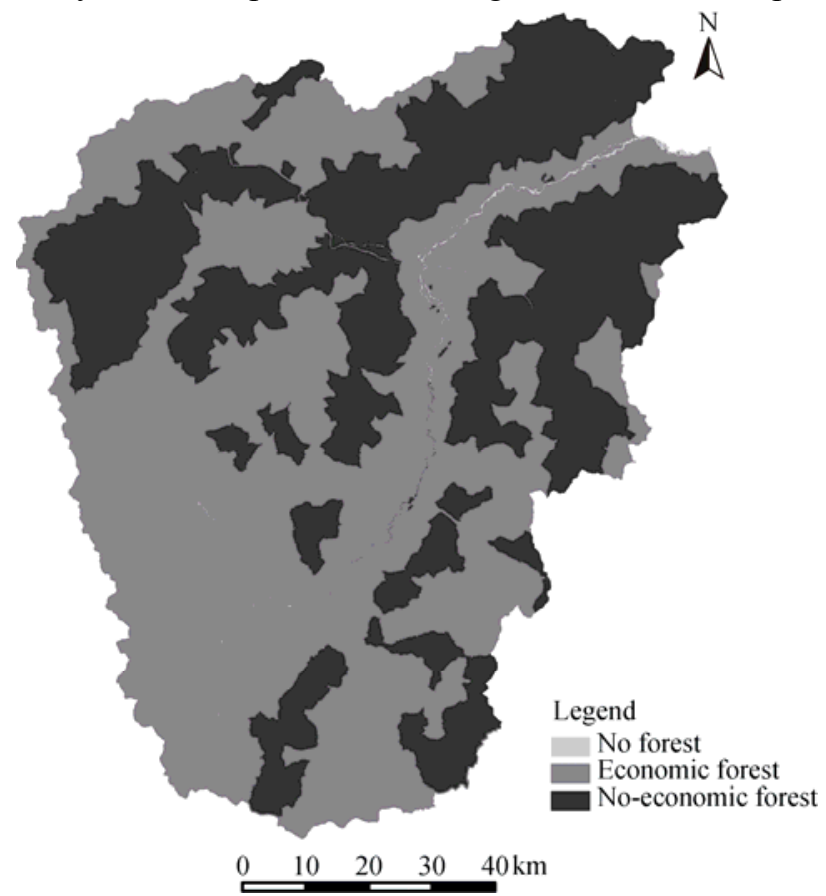

Fig. 2 Classification of forest management of Huzhong forest region

We used the metrics of mean patch area (MPA), percent area (PA) and aggregation index (AI) to quantify the changes of forest landscape patterns. Species distribution pattern was determined by the community characteristics, interspecific relationship and external disturbance (Berbert and Fagan, 2012). AI reflects the aggregation degree of species across the whole landscape (He et al., 2000). The higher of AI, the higher aggregation index of species. We used the ANOVA to analyze the changes of fuel loading, fire regime and forest landscape under different simulated harvesting modes.

\section{Results}

\subsection{Fuel loadings}

Fine fuel loadings generally decreased with the increase of timber harvesting intensity (Fig. 3). This is because timber harvesting removed the mature and over-mature forests that had higher fine fuel loadings than other age-class forests. In contrast, the timber harvesting increased the coarse fuel loadings, probably because timber harvesting activities produced more brush grouping, logs and stumps in the forests. The coarse fuel loadings under clear-cutting mode were higher than those under the selective-cutting and gradual-cutting modes (Fig. 4). There were significant differences of the coarse fuel loadings under different harvesting modes $(P<0.05)$ and no significant differences of the fine fuel loadings under timber harvesting modes $(P>0.05)$.

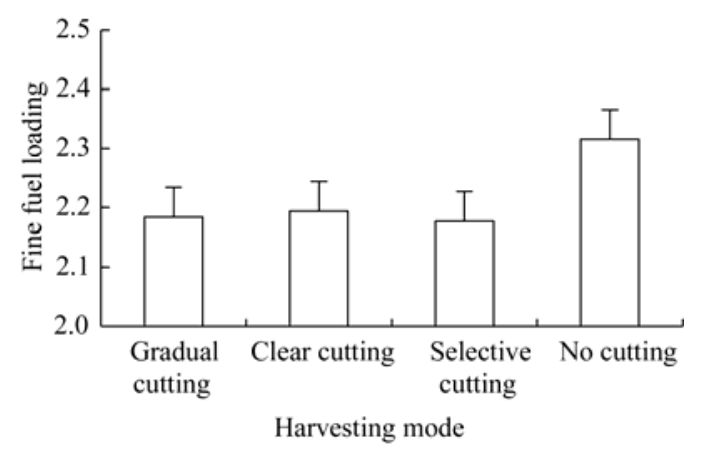

Fig. 3 Fine fuel loadings under different harvesting modes

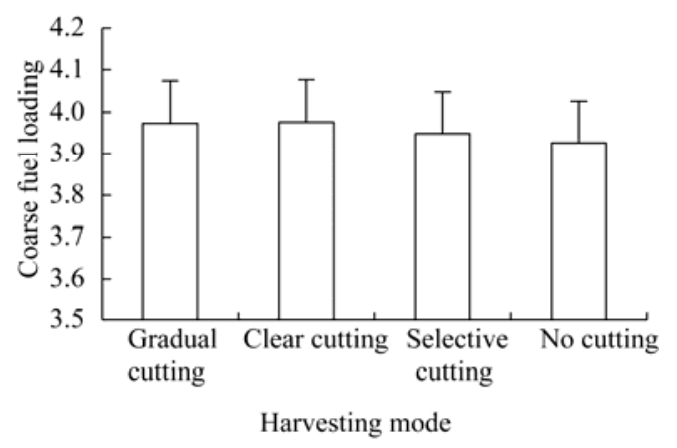

Fig. 4 Coarse fuel loadings under different harvesting modes

\subsection{Potential burn area}

The potential mean area burned in every decade under timber harvesting modes was higher than no timber harvesting mode (Fig. 5). Because the increase of the coarse fuel loading by human harvesting led to more ladder fuel, which was favor of forest fire spreading. Harvest makes light condition improve, and the forest humidity decrease, which increased the potential burn area in our simulation. The potential burn area was significantly different among cutting modes $(P<0.05)$.

\subsection{Potential fire frequency}

The results indicate that timber harvesting increased the potential fire frequency, probably because the harvesting generates more forest gaps, and these gaps would be occupied by broad-leaf species due to their 
strong seed dispersal and colonization ability. The broadleaf tree species in the early stage of forest succession were weak to fire disturbance, so timber harvesting increased the potential fire frequency (Fig. 6). We also compared the potential fire frequency under different cutting mode, and the result indicated that the potential fire frequency under different cutting modes had no obvious difference $(P>0.05)$.

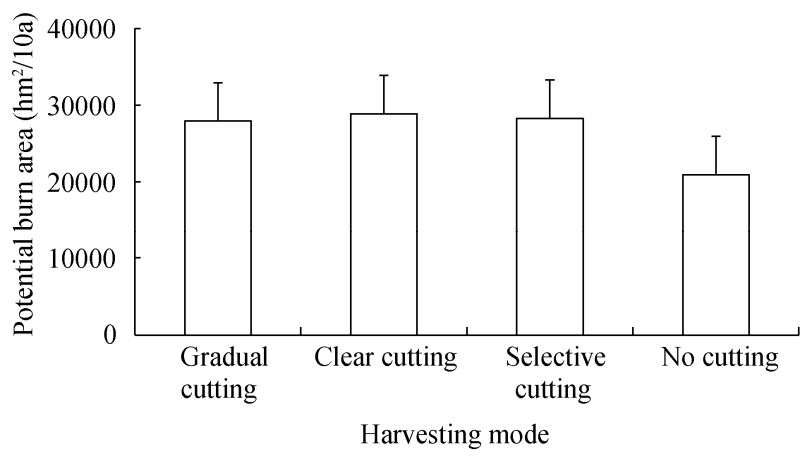

Fig. 5 Potential burn area under different harvesting modes

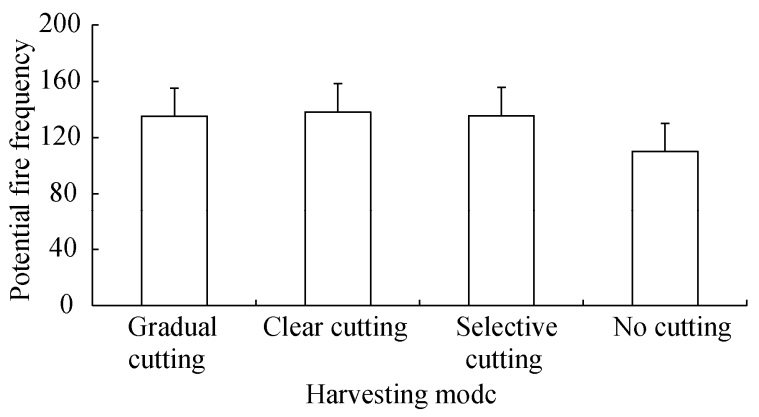

Fig. 6 Potential fire frequency under different harvesting modes

\subsection{Potential fire risk}

The potential fire risk under different harvesting modes presented that fire risk under gradual cutting was lower than those under clear cutting and selective cutting modes. This is because timber harvesting increased the coarse fuel loading, and timber harvesting led to more "ladder fuel" in the forest ecosystem, which was favor to the increase in forest fire intensity (Fig. 7). Moreover, fire risk under different cutting modes showed significant difference $(P<0.05)$.

\subsection{Forest landscape under different harvesting modes}

\subsubsection{Percent area of main species}

Percent of the area of larch cohorts was very similar under different cutting modes. Percent of the area of larch cohorts decreased between simulated 100 and

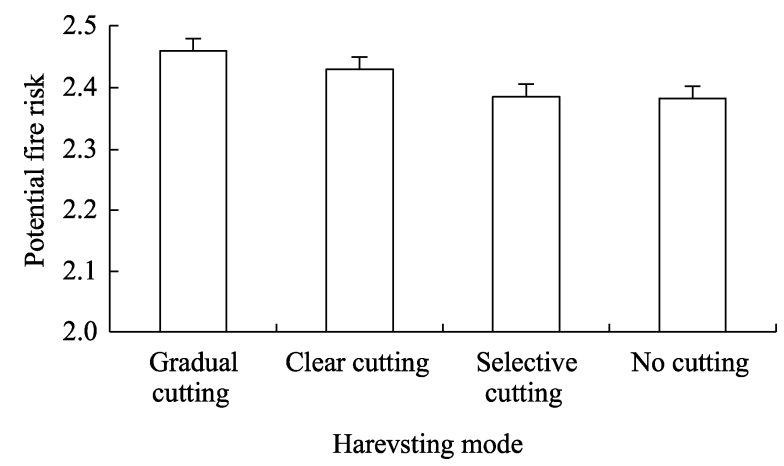

Fig. 7 Potential fire risk class under different harvesting modes

180 years and then increased under all harvesting modes as forest succession. Percent of the area of larch cohorts had no significant difference under different cutting modes $(P>0.05)$.

Percent of the area of white birch cohorts under different harvesting modes decreased before 120 years simulation, and then increased under every harvesting mode (Fig. 8). Percent of the area of white birch had no significant difference under different cutting modes $(P>0.05)$.
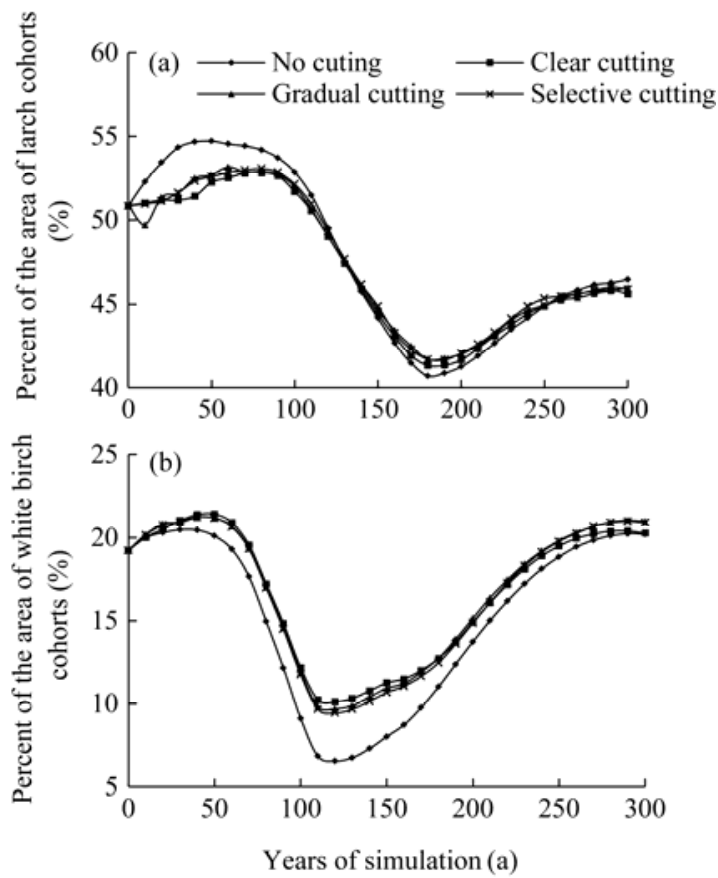

Fig. 8 Area percent of larch (a) and white birch (b) forests under different harvesting modes

\subsubsection{Aggregation index of main species}

The aggregation index (AI) of larch cohorts was between $0.70-0.95$, and timber harvesting decreased the AI of larch cohorts in the earlier stage. With forest succession, timber harvesting increased the AI of larch 
cohorts after 180 years simulation (Fig. 9). The AI of larch cohorts had no significant difference under different cutting modes $(P>0.05)$.

The AI of white birch under clear-cutting mode was higher than other harvesting modes $(P<0.05)$ (Fig. 9). Probably because all species were removed under clear-cutting, and white birch, a pioneer species, had strong transmission capacity, timber harvesting provided appropriate light condition for the growth and development of white birch cohorts.

\subsubsection{Mean patch area of main species}

Timber harvesting decreased the mean patch area of larch cohorts before 100 years simulation. However, the mean patch area of larch cohorts was similar under cutting and no cutting modes after 120 years simulation (Fig. 10). The mean patch area of larch cohorts under gradual-cutting mode was significantly higher than those under selective-cutting and clear-cutting modes $(P<0.05)$.

Timber harvesting increased the mean patch area of white birch cohorts before 180 years simulation (Fig. 10). The mean patch area of white birch cohorts under clear-cutting mode was higher than those under other harvesting modes, and the percent area of white birch cohorts had significant difference under different cutting modes $(P<0.05)$.

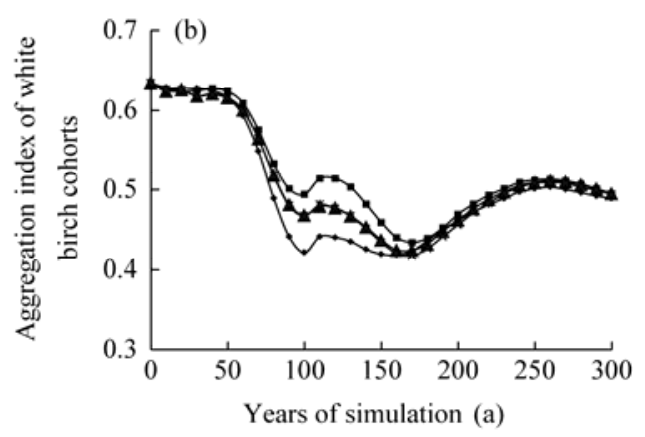

Fig. 9 Aggregation indexes of larch (a) and white birch (b) forests under different harvesting modes
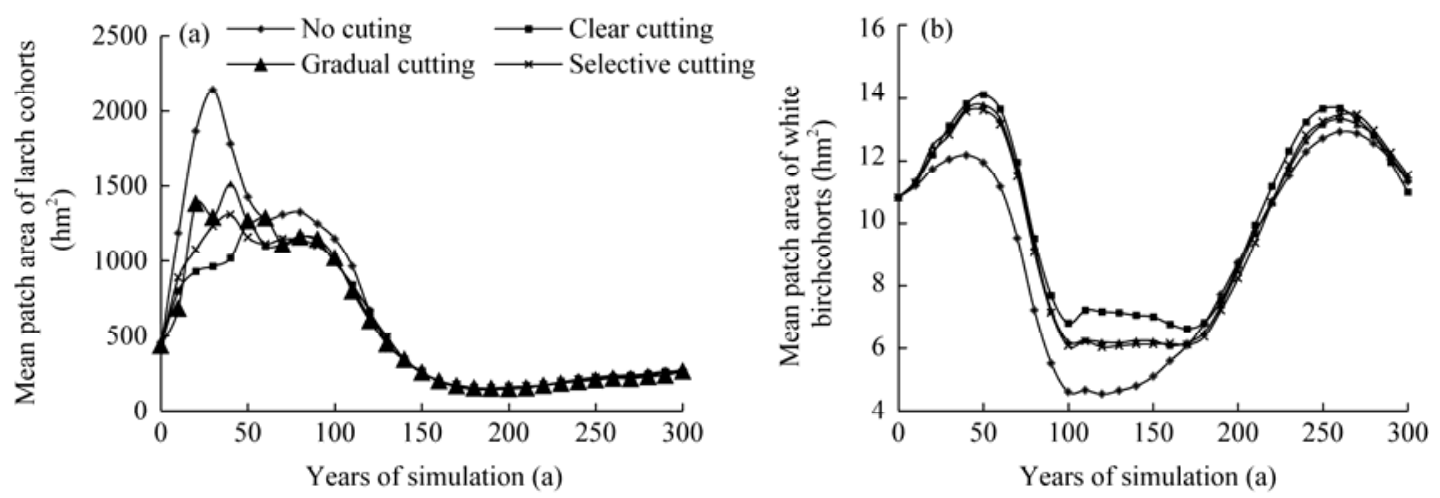

Fig. 10 Mean patch area of larch (a) and white birch (b) forests under different harvesting modes

\section{Discussion}

Previous studies indicated that human activities such as timber harvesting could greatly alter forest landscape patterns (Thompson et al., 2000). Therefore, it is important to employ fire models to evaluate the effects of human activity-induced changes on the forest landscape processes such as forest fire spreading (Finney,
2011). However, studies on the effects of timber harvesting on the forest fuel and fire regime are lack (Konoshima et al., 2008). Our study demonstrated the importance of timber harvesting in controlling fire regimes and forest landscape patterns in the Chinese boreal forest landscapes, which could provide references in other similar regions or ecosystems.

Our results showed that timber harvesting changed 
the patterns of fine and coarse fuel loadings in the Chinese boreal forests. Specifically, timber harvesting removed the mature and over-mature cohorts forests, which resulted in higher fine fuel loadings than other age-class forests and consequently resulted in the decrease of fine fuels. In contrast, timber harvesting increased the coarse fuel loadings because the harvesting produced more snags, logs and stumps in the forest floor layers (Pollet and Omi, 2002). It has been shown that coarse fuel loadings were the major factors which influenced the fire intensity (Konoshima et al., 2008). Moreover, our simulation results indicated that the coarse fuel loadings under clear-cutting mode were higher than those under other cutting modes. The clear-cutting mode would cause the loss of pioneer species and hinder the forest progressive succession (Carleton and MacLellan, 1994). It is well known that larch cohorts are the climax community, and clear-cutting decreased the percent area of larch cohorts (Xu, 1998). Therefore, abandoning the clear-cutting mode is suggested, and selective-cutting is recommended for the forest sustainable management.

Timber harvesting increased the fire frequency in Chinese boreal forests, which is consisting with Fall et al. (2004), who found that human management affected the fire regime in Canadian boreal forests. The simulation results indicated that timber harvesting improved light conditions in the forests, decreased fuel moisture, and consequently led to fire danger increases (Finney, 2001). We found that clear-cutting mode increased the fire risk and fire probability. Our results indicated that forest manager should take selective-cutting mode to manage forest fire, reduce the forest fire disaster in future and ensure forest sustainable development.

He et al. (2002a) compared the effects of timber harvesting and fire disturbance on foresee landscape patterns, and they found that timber harvesting presented stronger influence on tree species composition, age structure and spatial pattern of boreal forests. Forest management has become the most important landscape process that affects landscape pattern in many forests in northeastern of China (Liu et al., 2012). This study presented a modeling framework to evaluate the effects of timber harvesting modes on forest landscape patterns. Our results showed that timber harvesting decreased the percent of the area of larch cohorts between 100 and 180 years simulation, which subsequently provided favorable habitats for pioneer species (Mallik et al., 2014). Timber harvesting increased the percent of the area of white birch at first simulation stage. Many studies demonstrated that white birch was the pioneer species in the Great Khingan Mountains, and had strong germination capability (Hu et al., 2004). That is, white birch occupies forest gap quickly after timber harvesting. The most surprising result may be the percent of the areas of larch and white birch cohorts had no significant difference under different harvest modes. This is probably because there are some other factors that are not considered in this study such as harvesting intensity (Deal and Tappeiner 2002), micro topographical (Fleming et al., 2002) and meteorological factors (Baeza et al., 2002). White birch is a pioneer species, which is vulnerable to human and natural disturbances. In a word, timber harvesting decreased the forest stability, especially under clear cutting mode.

The LANDIS model cannot be used to identify forest for harvesting in the future decades (Shang et al., 2007). Landscape models provide a framework to conduct experiment with various harvesting modes and evaluate their long-term effects at a large spatial scale (Radeloff et al., 2006). This is because landscape modeling is challenged by the complex interactions of ecological processes at large spatial and temporal scales. There are a number of model assumptions that could affect our results and had to be taken into account when interpreting the model (He et al., 2002b; Birt et al., 2009). For example, LANDIS model only tracks species age-cohort absence or presence, not traces every individual tree, so it is a semi-quantitative model (Gardner et al., 2007; He, 2008), which can provide an effective evaluation of natural and human disturbances on the forest landscapes (Mladenoff, 2004; Sturtevant et al., 2009). However, at the landscape or regional scale, the information of species abundance and distribution generalized from the model simulation can be well presented (Mladenoff et al., 1996). Meanwhile, LANDIS model has complete evaluation procedures, which includes sensitivity analysis, uncertainty analysis and structural analysis 
(Mladenoff, 2004; Birt et al., 2009). Moreover, for improving the simulation accuracy, we changed the random number into 5 times during simulation, and the difference was less than $5 \%$. We could conclude that the LANDIS model is suitable for studying the harvesting activity effect on forest fire regime and landscape in the boreal forests of China.

\section{Conclusion}

Our research indicated that timber harvesting was an important factor affecting the fire regimes and forest landscapes. The fuel loading, potential fire area, fire probability and fire frequency were affected by different timber harvesting modes. At the same time, the spatial patterns of main forest species and forest landscape at a large spatial and temporal scale were also affected. Therefore, selective-cutting mode was recommended for the management of forest ecosystem. The result could provide references for the forest manager in the boreal forest of the Great Khingan Mountains.

\section{Acknowledgements}

This research was supported by the National Natural Science Foundation of China $(41201185,31070422$, 41271201), the Strategic Priority Research Program of the Chinese Academy of Sciences (XDA05050201) and the Agricultural Science and Technology Research Projects Foundation of Shenyang (F13-146-3-00). The DEM data were downloaded from the International Scientific \& Technical Data Mirror Site (http://datamirror.csdb.cn). We thank the anonymous reviewers for their constructive suggestions for improving the manuscript.

\section{References}

Baeza M, De Luís M, Raventós J, et al. 2002. Factors influencing fire behaviour in shrublands of different stand ages and the implications for using prescribed burning to reduce wildfire risk. Journal of Environmental Management, 65(2): 199-208.

Bataineh M, Kenefic L, Weiskittel A, et al. 2013. Influence of partial harvesting and site factors on the abundance and composition of natural regeneration in the Acadian Forest of Maine, USA. Forest Ecology and Management, 306: 96-106.

Berbert J M, Fagan W F. 2012. How the interplay between individual spatial memory and landscape persistence can generate population distribution patterns. Ecological Complexity, 12: 1-12.

Birt A G, Xi W M, Coulson R N. 2009. LANDISVIEW: A visualization tool for landscape modelling. Environmental Modelling \& Software, 24(11): 1339-1341.

Bond W J, Keeley J E. 2005. Fire as a global 'herbivore': The ecology and evolution of flammable ecosystems. Trends in Ecology \& Evolution, 20(7): 387-394.

$\mathrm{Bu}$ R C, He H S, Hu Y M, et al. 2008. Using the LANDIS model to evaluate forest harvesting and planting strategies under possible warming climates in Northeastern China. Forest Ecology and Management, 254(3): 407-419.

Carleton T J, MacLellan P. 1994. Woody vegetation response to fire versus clear-cutting logging: A comparative survey in the central Canadian boreal forest. Ecoscience, 1(2): 141-152.

Chang Y, He H S, Hu Y M, et al. 2008. Historic and current fire regimes in the Great Xing'an Mountains, Northeastern China: Implications for long-term forest management. Forest Ecology and Management, 254(3): 445-453.

Deal R L, Tappeiner J C. 2002. The effects of partial cutting on stand structure and growth of western hemlock-Sitka spruce stands in southeast Alaska. Forest Ecology and Management, 159(3): 173-186.

Fall A, Fortin M J, Kneeshaw D D, et al. 2004. Consequences of various landscape-scale ecosystem management strategies and fire cycles on age-class structure and harvest in boreal forests. Canadian Journal of Forest Research, 34(2): 310-322.

Finney M A. 2001. Design of regular landscape fuel treatment patterns for modifying fire growth and behavior. Forest Science, 47(2): 219-228.

Flannigan M, Stocks B, Turetsky M, et al. 2009. Impacts of climate change on fire activity and fire management in the circumboreal forest. Global Change Biology, 15(3): 549-560.

Fleming R A, Candau J-N, McAlpine R S. 2002. Landscape-scale analysis of interactions between insect defoliation and forest fire in central Canada. Climatic Change, 55(1-2): 251-272.

Foster D R, Knight D H, Franklin J F. 1998. Landscape patterns and legacies resulting from large, infrequent forest disturbances. Ecosystems, 1(6): 497-510.

Franklin J F, Forman R T. 1987. Creating landscape patterns by forest cutting: Ecological consequences and principles. Landscape Ecology, 1(1): 5-18.

Franklin J, Syphard A D, Mladenoff D J, et al. 2001. Simulating the effects of different fire regimes on plant functional groups in Southern California. Ecological Modelling, 142(3): 261-283.

Gardner R H, Romme W H, Turner M G. 1999. Predicting forest fire effects at landscape scales. In: Mladenoff D J, Baker W L. Spatial Modeling of Forest Landscape Change: Approaches and Applications. Cambridge: University Press, 163-185.

Gardner T A, Barlow J, Parry LW, et al. 2007. Predicting the uncertain future of tropical forest species in a data vacuum. Biotropica, 39(1): 25-30.

Gong X, Chang Y, Bu R C, et al. 2006. Long-term effects of different forest harvesting modes on forest landscape pattern in Huzhong Forestry Bureau. Chinese Journal of Ecology, 25(7): 805-812. (in Chinese)

Gustafson E J, Shifley S R, Mladenoff D J, et al. 2000. Spatial simulation of forest succession and timber harvesting using LANDIS. Canadian Journal of Forest Research, 30(1): 32-43.

He H S, Mladenoff D J. 1999. Spatially explicit and stochastic simulation of forest-landscape fire disturbance and succession. Ecology, 80(1): 81-99.

He H S, DeZonia B E, Mladenoff D J. 2000. An aggregation index (AI) to quantify spatial patterns of landscapes. Landscape Ecology, 15(7): 591-601.

He H S, Mladenoff D J, Gustafson E J. 2002a. Study of landscape 
change under forest harvesting and climate warming-induced fire disturbance. Forest Ecology and Management, 155(1-3): 257-270.

He H S, Hao Z Q, Larsen D R, et al. 2002b. A simulation study of landscape scale forest succession in northeastern China. Ecological Modelling, 156(2-3): 153-166.

He H S, Shang B Z, Crow T R, et al. 2004. Simulating forest fuel and fire risk dynamics across landscapes-LANDIS fuel module design. Ecological Modelling, 180(1): 135-151.

He H S. 2008. A review of LANDIS and other forest landscape models for integration with wildlife models. In: Millspaugh J J, Thompson F R. Models for Planning Wildlife Conservation in Large Landscapes. Burlington, MA: Academic Press, 321-338.

Hu Y M, Xu C G, Chang Y, et al. 2004. Application of spatially explicit landscape model (LANDIS): A case researches in Huzhong area, Mt. Daxing'anling. Acta Ecologica Sinica, 24(9): 1846-1856. (in Chinese)

Hunter M L Jr. 1993. Natural fire regimes as spatial models for managing boreal forests. Biological Conservation, 65(2): 115-120.

Keane R E, Cary G J, Flannigan M D, et al. 2013. Exploring the role of fire, succession, climate, and weather on landscape dynamics using comparative modeling. Ecological Modelling, 266: 172-186.

Konoshima M, Montgomery C A, Albers H J, et al. 2008. Spatial-endogenous fire risk and efficient fuel management and timber harvest. Land Economics, 84(3): 449-468.

Liu Z H, He H S, Yang J. 2012. Emulating natural fire effects using harvesting in an eastern boreal forest landscape of northeast China. Journal of Vegetation Science, 23(4): 782-795.

Liu Z H, Yang J, He H S. 2013. Studying the effects of fuel treatment based on burn probability on a boreal forest landscape. Journal of Environmental Management, 115: 42-52.

Lorimer C G. 1977. The presettlement forest and natural disturbance cycle of northeastern Maine. Ecology, 58(1): 139-148.

MacDonald R L, Chen H Y H, Palik B P, et al. 2014. Influence of harvesting on understory vegetation along a boreal riparian-upland gradient. Forest Ecology and Management, 312: 138-147.

Mallik A U, Kreutzweiser D P, Spalvieri C M. 2014. Forest regeneration in gaps seven years after partial harvesting in riparian buffers of boreal mixedwood streams. Forest Ecology and Management, 312: $117-128$.

Mladenoff D J, Host G E, Boeder J R, et al. 1996. LANDIS: A spatial model of forest landscape disturbance, succession, and management. In: GIS and Environmental Modeling: Progress and Research Issues. Fort Collins, CO, USA: GIS World Books, 175-180.

Mladenoff D J, He H S. 1999. Design, behavior and application of LANDIS, an object-oriented model of forest landscape disturbance and succession. In: Mladenoff D J, Baker W L. Spatial Modeling of Forest Landscape Change: Approaches and Applications. Cambridge: Cambridge University Press, $125-162$.

Mladenoff D J. 2004. LANDIS and forest landscape models. Ecological Modelling, 180(1): 7-19.

Pausas J G. 2006. Simulating Mediterranean landscape pattern and vegetation dynamics under different fire regimes. Plant Ecology, 187(2): 249-259.
Pollet J, Omi P N. 2002. Effect of thinning and prescribed burning on crown fire severity in ponderosa pine forests. International Journal of Wildland Fire, 11(1): 1-10.

Radeloff V C, Mladenoff D J, Gustafson E J, et al. 2006. Modeling forest harvesting effects on landscape pattern in the Northwest Wisconsin pine barrens. Forest Ecology and Management, 236(1): 113-126.

Rudnicky T C, Hunter M L. 1993. Avian nest predation in clearcuts, forests, and edges in a forest-dominated landscape. The Journal of Wildlife Management, 57(2): 358-364.

Rüger N, Gutiérrez Á G, Kissling W D, et al. 2007. Ecological impacts of different harvesting scenarios for temperate evergreen rain forest in southern Chile-A simulation experiment. Forest Ecology and Management, 252(1-3): 52-66.

Shang Z B, He H S, Lytle D E, et al. 2007. Modeling the long-term effects of fire suppression on central hardwood forests in Missouri Ozarks, using LANDIS. Forest Ecology and Management, 242(2-3): 776-790.

Sturtevant B R, Gustafson E J, Li W, et al. 2004. Modeling biological disturbances in LANDIS: A module description and demonstration using spruce budworm. Ecological Modelling, 180(1): 153-174.

Sturtevant B R, Scheller R M, Miranda B R, et al. 2009. Simulating dynamic and mixed-severity fire regimes: A process-based fire extension for LANDIS-II. Ecological Modelling, 220(23): 3380-3393.

Thompson W A, Vertinsky I, Schreier H, et al. 2000. Using forest fire hazard modelling in multiple use forest management planning. Forest Ecology and Management, 134(1-3): 163-176.

Turner M G. 1989. Landscape ecology: The effect of pattern on process. Annual Review of Ecology and Systematic, 20(1): 171-197.

Turner M G, Gardner R H, O'Neill R V. 2001. Landscape Ecology in Theory and Practice: Pattern and Process. New York: Springer, 78-93.

Wallin D O, Swanson F J, Marks B, et al. 1996. Comparison of managed and pre-settlement landscape dynamics in forests of the Pacific Northwest, USA. Forest Ecology and Management, 85(1-3): 291-309.

Wang X G, He H S, Li X Z. 2007. The long-term effects of fire suppression and reforestation on a forest landscape in Northeastern China after a catastrophic wildfire. Landscape and Urban Planning, 79(1): 84-95.

Wu Z W, He H S, Chang Y, et al. 2011. Development of customized fire behavior fuel models for boreal forests of Northeastern China. Environmental Management, 48(6): 1148-1157.

Xu H C. 1998. Da Hinggan Ling Mountains Forests in China. Beijing: Science Press, 1-231. (in Chinese)

Yang J, He H S, Gustafson E J. 2004. A hierarchical fire frequency model to simulate temporal patterns of fire regimes in LANDIS. Ecological Modelling, 180(1): 119-133.

Zhang H R, Tang S Z. 2007. Review on the study of ecology-based forest harvesting. Scientia Silvae Sinicae, 9: 83-87. (in Chinese)

Zhou Y L. 1991. Vegetation in Great Xing'an Mountains of China. Beijing: Science Press, 1-216. (in Chinese) 